ДУБИНА Альбина Шагидулловна - кандидат социологических наук, доцент кафедры экономической теории и международных отношений Пензенского государственного университета (440026, Россия, г. Пенза, ул. Красная, 40; Misurin@bk.ru)

\title{
ЕАЭС КАК ДРАЙВЕР ИНТЕГРАЦИИ НА ПОСТОВЕТСКОМ ПРОСТРАНСТВЕ
}

\begin{abstract}
Аннотация. В работе исследуется Евразийский экономический союз в качестве важного участника мировой экономики, наделенного полноценной правосубъектностью. Автор описывает текущее положение дел в области евразийской интеграции по вопросам международного сотрудничества с акцентом на сотрудничество с межправительственными организациями и интеграционными объединениями, анализирует особенности формирования единого политического и экономического евразийского пространства на территории постсоветского пространства.

Актуальность статьи заключается в том, что сегодня ЕАЭС - это одно из самых перспективных объединений на евразийском пространстве, которое обладает большим потенциалом к дальнейшему расширению и развитию. За время существования ему удалось добиться определенных успехов как внутри самого ЕАЭС, так и на международной арене. Автор анализирует этот опыт, и на его основе определяет дальнейшие перспективы развития Евразийского экономического союза на современном этапе.
\end{abstract}

Ключевые слова: интеграция, глобальное регулирование, наднациональность, международные отношения, международные экономические организации, постсоветское партнерство, ЕАЭС, СНГ, ЕС

$\mathrm{C}$ о второй половины XX в. в мире появляется тенденция образования новых региональных структур, целью деятельности которых является взаимовыгодное сотрудничество в экономической, политической, культурной и военной сферах. Таким образом, одновременно с усилением процессов глобализации свое развитие получили и региональные интеграционные процессы.

Таким образом, и образование ЕАЭС было не случайным - союз возник в ответ на возникшие геополитические вызовы. Одной из важнейших предпосылок принято считать образование Евразийского экономического сообщества (ЕврАзЭС). Данная организация действовала с 2001 по 2014 г. Главной целью ЕврАзЭС являлось углубление интеграции в экономической и гуманитарной областях. ЕврАзЭС было ликвидировано 10.10.2014 в связи с началом функционирования ЕАЭС [Ермохина 2016: 21].

По словам президента РФ В.В. Путина, ЕАЭС в своей деятельности опирается на доступные для общего понимания механизмы работы, которые не противоречат принципам Всемирной торговой организации. Союз выступает драйвером интеграционных процессов на постсоветском пространстве, аккумулируя вокруг себя мощный центр экономического развития ${ }^{1}$.

На сегодняшний день в состав интеграционного объединения входят пять стран-участниц: Республика Армения, Республика Беларусь, Республика Казахстан, Киргизская Республика, Российская Федерация и три государства в статусе наблюдателя: Молдавия, Узбекистан и Куба. Кроме того, в зону свободной торговли (ЗСТ) ЕАЭС входят: Вьетнам, Иран, Сербия и Сингапур. Еще 6 государств (Египет, Израиль, Индия, Китай, Монголия и Таиланд) находятся на стадии переговоров о вступлении в ЗСТ ЕАЭС. Около 50 стран выражали

1 Путин В. Евразийский экономический союз будет работать по универсальным и понятным правилам. - ТАСС. 29 мая 2014. Доступ: https://tass.ru/ekonomika/1223933 (проверено 18.11.2021). 
желание сотрудничать с ЕАЭС ${ }^{1}$. Из этого можно сделать вывод, что ЕАЭС имеет перспективу расширения.

Стоит отметить, что целью ЕАЭС является объединение не только постсоветских государств; ЕАЭС должен стать мостом между Европой и АзиатскоТихоокеанским регионом. В последнее время поднимается вопрос о развитии отношений с ЕС, или «интеграциии интеграций». Кроме того, эксперты обращают внимание на смену традиционной парадигмы «Большой Европы от Лиссабона до Владивостока» на новую парадигму «Большой Евразии от Лиссабона до Шанхая».

В 2020 г. Узбекистан и Куба получили статус наблюдателей ЕАЭС, а Иран получил одобрение начала переговоров по соглашению о свободной торговле. В связи с пандемией ЕЭК были определены ключевые меры по борьбе с распространением коронавирусной инфекции COVID-19.

На уровне глав государств был принят Стратегический план расширения и продвижения евразийской интеграции на следующую пятилетку. Документ состоит из 11 направлений, которые содержат 332 меры. К 2025 г. планируется заключить 13 международных договоров, разработать 60 правовых актов ЕАЭС и внести 25 поправок в договор о ЕАЭС.

Стратегические направления развития евразийской интеграции до 2025 г. впервые включают в себя международную деятельность как ключевую сферу. География международного сотрудничества включает в себя следующие векторы развития:

- Европа - ЕС и государства региона;

- Азия - АСЕАН, ШОС, Индия, КНР и прочие государства региона;

- Африка - Африканский союз и государства региона;

- Латинская Америка - Тихоокеанский альянс, МЕРКОСУР, Андское сообщество наций и государства региона;

- другие объединения.

На лето 2021 г. запланирован запуск цифрового проекта «Работа без границ». Его идея заключается во внедрении поисковой системы, которая даст доступ к получению информации о свободных вакансиях на рынке труда стран - членов ЕАЭС. Данный проект способен усилить взаимодействие рынков труда ЕАЭС [Дубина, Чернова, Шмонина 2020: 21].

Таким образом, можно сделать вывод, что ЕАЭС за 6 лет своей деятельности добился определенных успехов, включая развитие цифровой экономики, формирование общего рынка товаров, принятие таможенного кодекса, реализацию проектов, направленных на социальную сферу. Кроме того, у ЕАЭС появились 3 государства-наблюдателя и 4 страны, входящие в зону свободной торговли ЕАЭС, что говорит о привлекательности объединения для третьих стран. Также были выделены стратегические направления развития евразийской интеграции. Следует также заметить, что союз в период пандемии не только сохранился, но и усилился. Степень его интеграции возрастает.

Сегодня ЕАЭС на постсоветском пространстве является наиболее перспективным объединением. 1.01.2021 ЕАЭС отметил свое шестилетие. За этот небольшой срок своей работы ЕАЭС удалось достичь определенных успехов. Главными итогами за данный период работы являются:

- расширение ассортимента товаров и услуг, в большей степени на рынке продовольственных товаров;

- формирование наднациональных органов объединения;

- формирование единого рынка труда работников;

${ }^{1}$ Евразийский экономический союз. Доступ: http://www.eaeunion.org (проверено 18.11.2021). 
- создание нормативно-правовой базы;

- развитие цифровой экономики;

- принятие Таможенного кодекса;

- активное сотрудничество с третьими странами и другими интеграционными объединениями.

В рейтинге Doing Business в 2020 г. из 190 исследуемых государств ЕАЭС занимает 29-е место. Динамика позиций, которые занимал ЕАЭС, представлена на рис. 1. Стоит отметить, что с каждым годом наблюдается укрепление позиции ЕАЭС.

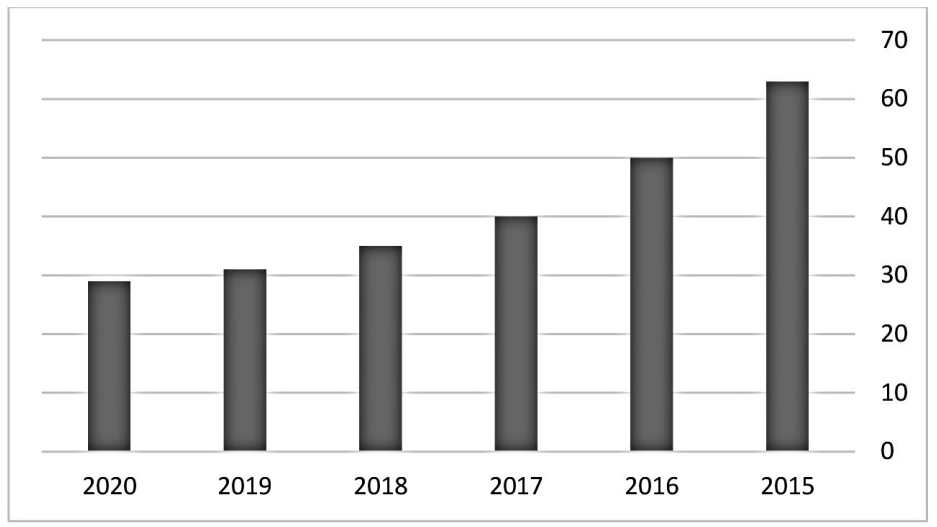

Рисунок 1. Позиция ЕАЭС в рейтинге Doing Business в 2020 г. [Ефименко 2020: 56].

Тем не менее за это время определился ряд проблем, которые мешают более эффективной интеграции стран ЕАЭС. Одной из главных проблем является преобладание сырьевых продуктов в структуре экспорта участников ЕАЭС. Данная экспортная направленность может тормозить экономический рост из-за большого колебания цен на них.

Еще одна проблема - разный уровень экономического развития участников объединения. По большинству показателей деятельности ЕАЭС явным лидером является Россия. По этой причине Россия в некоторых случаях выступает главным каналом переговоров с третьими сторонами (например, ЕС и Китай).

Кроме того, российские ученые И. Зеленева и В. Агеева в одной из своих работ отмечают, что концепция русского мира является преобладающей в идеологии евразийской интеграции [Зеленева, Агеева 2018: 742]. Данный факт может усложнить процесс интеграции стран ЕАЭС. Согласно концепции, Россия занимает главное место в определении политического и культурного курса. Также идея русского мира предполагает православную культуру, тогда как большую часть населения Казахстана и Киргизии составляют мусульмане. Вопросы религии усложняют диалог. Однако стоит отметить, что Россия многоконфессиональное государство, и при этом всего 6\% населения страны исповедуют ислам.

Следующей проблемой является разность интересов стран - участниц ЕАЭС. Целью России является поддержание устойчивого экономического роста и укрепление международного имиджа. Для Беларуси цель состоит в диверсификации рынка в рамках ЕАЭС, Казахстан стремится укрепить свое положение в Центрально-Азиатском регионе. Члены ЕАЭС пытаются проводить многовекторную внешнюю политику, что вызывает, в конечном итоге, отклонение их обязательств в рамках ЕАЭС от практики. 
Кроме того, деятельность ЕАЭС затрудняется в условиях пандемии, связанной с распространением коронавирусной инфекции. «Нынешняя ситуация является испытанием для всего Союза», - заявил глава Киргизии в 2020-2021 гг. Экономическая активность начала снижаться из-за карантинных мер, кроме того, в данном вопросе присутствует фактор неопределенности, который мешает планированию и осуществлению ранее поставленных задач. Н. Коровникова выделяет 3 вероятных сценария развития событий: мягкий, средний и жесткий. Первый характеризуется быстрым восстановлением всех секторов экономики, по среднему варианту на это понадобится 2-3 года, последствия жесткого сценария сравнимы с положением России в 1990-х гг. [Коровникова 2020: 345].

Что касается перспектив развития ЕАЭС, то у объединения есть два варианта пути развития. Первый - экстенсивный путь, он основан на увеличении числа участников ЕАЭС. Эта идея поднималась с самого начала работы ЕАЭС. Сегодня ЕАЭС имеет 3 страны-наблюдателя, в его ЗСТ входят 4 государства. Около 50 стран выражают желание сотрудничать с ЕАЭС. В работе уже были рассмотрены основные направления развития интеграции, которые охватывают 3 региона мира - Европу, Азию и Латинскую Америку.

Кроме того, в последнее время все чаще поднимается вопрос о развитии сотрудничества с Индией и Турцией (как правило, в данном случае говорится только о создании ЗСТ). Что касается присоединения нового участника ЕАЭС, то включение Таджикистана в ЕАЭС является на данный момент самым реалистичным. Страны - члены ЕАЭС уже имеют экономические связи с Таджикистаном; это государство ведет активную деятельность в процессе евразийской интеграции (Таджикистан входит в ЕБР и ОДКБ). В настоящее время Таджикистан изучает и оценивает все возможные выгоды и риски присоединения. По данным ЕБР, 69\% жителей страны положительно относятся к развитию интеграции Таджикистана и ЕАЭС ${ }^{1}$.

Второй путь - интенсивный, он характеризуется развитием интеграции внутри ЕАЭС. ЕАЭС активно занимается своим реформированием. Так, например, к 2025 г. планируется реализовать нескольких крупных проектов. Первый из них - это Финансовый регулятор ЕАЭС. Он будет переставлять собой наднациональное финансовое учреждение, расположенное в Казахстане. Главная его цель - соблюдение стандартов ЕАЭС на финансовых рынках. Формирование общего финансового рынка является одной из приоритетных задач ЕАЭС. Кроме того, планируется создать еще один общий рынок - рынок нефти, газа и нефтепродуктов, который будет реализован в рамках двух программ.

Стоит отметить, что для более гармоничного развития ЕАЭС может объединить экстенсивный и интенсивный пути в один.

Однако главными проблемами ЕАЭС являются зависимость от экспорта энергоресурсов, ориентация участников ЕАЭС на получение собственной выгоды без учета интересов стран-партнеров. Кроме того, существуют проблемы, связанные с неравномерным уровнем экономического развития.

Несмотря на ряд проблем, все же, подводя итоги, можно резюмировать, что сегодня ЕАЭС является перспективной международной организацией региональной экономической интеграции, которая является мощным драйвером развития политического и экономического сотрудничества стран на постсоветском пространстве, а также имеет значительный потенциал к постепенному их расширению и развитию.

1 Интеграционный барометр ЕАБР 2017. Доступ: https://eabr.org/analytics/integrationresearch/cii-reports/integratsionnyy-barometr-eabr-2017/ (проверено 18.11.2021). 


\section{Список литературы}

Дубина А.Ш., Чернова 3.М., Шмонина Е.Н. 2020.Трудовая миграция на постсоветском пространстве: современное состояние и особенности. Системное обеспечение условий достойного труда: материалы II Всероссийской научно-практической конференции. Новосибирск, 22 ноября 2019 г. (отв. ред. В.И. Мельников). Новосибирск: Изд-во СГУПС. С. 19-24.

Ермохина И.В. 2016. ЕАЭС - новый этап евразийской интеграции. - Символ науки. № 4. С. 20-23.

Ефименко М.А. 2020. ЕАЭС в рейтинге Doing Business-2020. - Экономика и бизнес: теория и практика. № 5. С. 55-57.

Зеленева И.В., Агеева В.Д. 2018. Идеология евразийской интеграции. Постсоветские исследования. № 8. С. 736-745.

Коровникова Н.А. 2020. Тенденции развития проекта ЕАЭС в контексте кризиса COVID-19. - Большая Евразия: Развитие, безопасность, сотрудничество. № 3. C. 343-346.

DUBINA Albina Sagidullaevna, Cand.Sci. (Soc.), Associate Professor of the Chair of Economic Theory and International Relations, Penza State University (40 Krasnaya St, Penza, Russia, 440026; Misurin@bk.ru)

\section{THE EAEU AS A DRIVER OF INTEGRATION IN THE POST-SOVIET SPACE}

\footnotetext{
Abstract. The paper examines the Eurasian Economic Union in the system of international relations. The author identifies the EAEU as an important participant in the world economy endowed with a full-fledged legal personality. The current state of affairs in the field of Eurasian integration on issues of international cooperation with an emphasis on cooperation with intergovernmental organizations and integration associations is described. The article also analyzes the features and problems of the formation of a single political and economic Eurasian space on the territory of greater Eurasia. The relevance of the article lies in the fact that today the EAEU is one of the most promising associations in the Eurasian space. In addition, the EAEU has a great potential for further expansion and development. During this time, it managed to achieve some success, both within the EAEU itself and in the international arena. The paper analyzes this experience, and based on it, determines further prospects for the development of the Eurasian Economic Union at the present stage. Keywords: integration, global regulation, supranationality, international relations, international economic organizations, Great Eurasian Partnership, EAEU, CIS, EU
} 